\title{
Presidential Election and Vice President of the Republic of Indonesia Based on Pancasila Democratic Principles
}

\author{
Yusuf Mustafa \\ Student of Law Doctoral Program, Faculty of Law, Universitas 17 Agustus 1945 Surabaya \\ Made Warka \\ Lecturer of Law Doctoral Program, Faculty of Law, Universitas 17 Agustus 1945 Surabaya \\ Hufron \\ Lecturer of Law Doctoral Program, Faculty of Law, Universitas 17 Agustus 1945 Surabaya
}

\begin{abstract}
Pancasila (the Indonesian five tenets) as the ultimate of All the Sources of Laws in Indonesia is actually the basis for the formation of legislation regarding the Election of the President and Vice President. The precepts of Pancasila that is relevant to the system of the President and Vice President is the fourth tenets. Practically, the system for filling in the positions of the President and Vice President must be carried out in accordance with the values contained in the fourth principle of the Pancasila. The implementation is based on a combination of the system of citizen sovereignty (democracy) and the fourth tenets of Pancasila, so that the combined system of the two (citizen sovereignty and fourth principle) gives birth to the "Pancasila Democracy" system.It is important to analyze and find the system for selecting the President and Vice President of the Republic of Indonesia based on the principles of Pancasila Democracy.This research is normative research which focuses on the level of harmonization or system related to the President and Vice President of the Republic of Indonesia directly by the people based on popular principles led by the wisdom of decisions in consultations (Pancasila democracy). From the results of the discussion and analysis, conclusions are obtained as answers to the problems proposed as follows: (1) Philosophically that the essence of the meaning of "People led by wisdom in consultation / representation" is democracy, namely the government of the people, by the people, and for the people, based on the principle: (a) Consultation, which is to make a unanimous decision, carried out jointly through the road of wisdom; (b) Carry out decisions based on honesty. Decisions are unanimous so that they bring consequences to mutual honesty. (c) Population principles, namely a sense of love for the people, fighting for people's ideals, and having a people's spirit. The fourth Sila Meaning of Pancasila is a democratic-representative system led by people who are professional and have integrity through a system of deliberation to reach consensus to get the best results from a round of political decisions. (2) The system of electing the President and Vice President of the Republic of Indonesia in accordance with popular principles led by wisdom of wisdom in deliberation / representation is a model of the election of representative democracy with a system of deliberation to reach consensus. Whereas the direct democratic system is only implemented to elect representatives who will occupy positions as representative bodies to carry out deliberations for consensus in the election of the President and Vice President of the Republic of Indonesia.
\end{abstract}

Keywords: direct election, democracy, Pancasila, Indonesian election

DOI: $10.7176 / \mathrm{JLPG} / 88-01$

Publication date: August $31^{\text {st }} 2019$

\section{Prelude}

Indonesia has a state-of-the-line constitutional system. That commitment can be seen in the dynamics of the change of 1945 Constitution of the Republic of Indonesia (UUD 1945). Four times the amendment of the 1945 Constitution does not alter the provisions of article 1 paragraph (1) 1945 Constitution stating, "The state of Indonesia is a unitary state in the form of Republic."

The word "Republic" indicates a system of charging power is not carried out in a hereditary state as applicable in the monarchy. Duguit in Moh. Kusnardi and Harmaily Ibrahim said that, distinguishing between the Republic and the monarchy was the mechanism of head of State lifted. When the head of state is appointed by inheritance or hereditary rights, the form of government is called Monarkhi and the executor is called King. Whereas, if the head of State was elected through a elections for a particular term, then The country's system is called the Republic and its head.

In fact, the Republican system cannot be released from the democratic system which is the basis for the implementation of the elections in the charging of the office and/or Vice president. Before the amendment, the sovereignty of the people's implementation was at the hands of the People's Consultative Assembly (MPR). Then on the third amendment there is a change in article 1 paragraph (2) indicating there has been a shift from the Supremacy of Parliament to the Supremacy of the Constitution. Article 1 paragraph (2) 1945 Constitution states, 
"Sovereignty is in the hands of the people and is implemented under the Constitution."

Article 6A of 1945 Constitution which became the Constitutional foundation of the presidential election and the vice president directly by the people. The spouse of the presidential candidate and vice president is proposed by the political party or the political party coalition of the elections before the election implementation.

The basic principles of the implementation of elections directly by the people based on article 22E paragraph (2) of 1945 Constitution is conducted to select members of the House of Representatives (DPR), members of the Regional Reprenstative Council (DPD), President and vice president, and members of the Local Parliament (DPRD). Such provisions shall not be waived from the principle of elections contained in article 22E paragraph (1) of 1945 Constitution which states, "elections are conducted in a direct, public, free, confidential, honest and fair every five years." Maybe can look in the future that problem is when the candidate listed in the empty ballot has been elected by the community but the chosen one does not win, then such election is actually not of the will of the community. People who have partially alienated in a certain period of time to the government will become a rejection. Many things happen in it such as money politics, the proximity of candidates to party leaders to the performance of candidates that deserve to be taken into account. The thought of future elections must change from this moment when the candidate is still a natural human being, so that changes in will or conflicts of will always occur. There is no more legal justice as the highest legal goal because candidates still use logic in campaigning. With the development of time and technology, the choice of an electoral system oriented to human candidates should turn into an election with artificial intelligence, namely robots. ${ }^{1}$

To ensure the implementation of qualified presidential election and vice president, fulfilling the degree of competition that is healthy, participatory, and accountable, it is necessary to be established a law on Presidential elections and appropriate Vice president with the development of democracy and the dynamics of society in the life of nation and state. When referring to the theory of "Stufenbau Des Recht" presented by Hans Kelsen and Hans Nawiasky, the main reference of the system is the basic norms or fundamental norms of the State (Staatfundamentals norm/grundnorm) in Indonesia known With Pancasila. The basic norm of the country (Staatfundamentals norm) is the highest reference that is the basis for the establishment of legislation, both the Constitution of the state (Staatgrund gezets) and the rules below.

The Staatsfundamentalnorm or Grundnorm, which is a legal mind, has a regulatory function and a constituent function. The legal Mind has a (1) regulative function as a benchmark that is to test whether a positive law is fair or not. As for the constitutif (2) function, that is to determine that without a legal mind, the law will lose its meaning as a law. As a legal ideals, Pancasila can fulfill the functions of the constituent and the regulatory functions. Through the constituent function, Pancasila determines the basis of a legal ordinance that gives meaning and meaning to the law itself. Similarly, the regulative function of Pancasila determines whether a positive law is a fair or unfair product. As the statute of the Pancasila is the root of the derivation (source of the description) from the Indonesian order of law including the 1945 Constitution. ${ }^{2}$

Pancasila as the source of the sources of the state law is normatively affirmed in article 2 of Act No. 12 of 2011 on the establishment of legislation. Such provisions implicates that, any statutory legislation established by the State should reflect the values of Pancasila in each of the norms that are outlined in the legislation. That is, the norm that is contained in the legislation should be the derivation of the values embodied in Pancasila. Thus, it is absolutely legal to adopt each of the precepts in Pancasila as the principle contained in any legislation in Indonesia.

As for the Sila from Pancasila that is relevant to the system President and vice president is the fourth Sila. Practically, the filling system of the office of President and Vice president must be implemented in accordance with the values contained in the fourth sila of Pancasila. Therefore, the fourth sila of Pancasila should be the main reference in the system of presidential election and vice president in Indonesia. Implementation based on the combination of the People's Sovereignty system (democracy) and the fourth sila of Pancasila, so that the combined system of both (people's sovereignty and the fourth sila) gave birth to the system of "Pancasila democracy". Therefore, it is important to analyze and find the presidential election system and vice President of the Republic of Indonesia based on the principle of Pancasila democracy.

\section{Research Methods}

This research is a normative research that focuses on the level of harmonization or synchronization related to the electoral system of the President and vice President based on the principle of Pancasila democracy. Normative research is also called doctrinal Law research or literature research or document study, because it is aimed at written rules or other legal materials. ${ }^{3}$ Soetandyo Wignjosoebroto in Bambang Sunggono called normative

\footnotetext{
${ }^{1}$ Tomy Michael, General Election And The Study Of the Future, Jurnal Notariil, Vol. 3, No. 2, November 2018, $130-136$.

${ }^{2}$ Kaelan, Aktualisasi Pancasila Dalam Kehidupan Berbangsa Dan Bernegara, 5 Juni 2017, Universitas 17 Agustus 1945 Surabaya, hlm 3.

${ }^{3}$ Suratman dan Philips Dillah, Metode Penelitian Hukum, Alfabeta, Bandung, 2015, h.51.
} 
research as a study of legal principles. ${ }^{1}$

This research uses 4 (four) kinds of approaches including: (a) Statute approach, especially the 1945 Constitution of the Republic of Indonesia and the Act on Elections; (b) Conceptual approach, which is to examine the legal concepts, legal resources, legal functions and legal institutions about the presidential and vice president election system based on the principle of the circumcision led by wisdom In a consultative/representative; (c) Historical approach through several academic manuscripts and manuscripts of the 1945 Constitution of the Republic of Indonesia and the Law on Elections to determine the legist ratio and the original intent of these acts; (d) Philosophical approach, which is to examine the nature of the presidential election system and vice president based on the principle of the populist led by wisdom in the consultative/representative.

\section{Discussion of the nature of Pancasila democracy}

If a country does not implement elections the country is not called a democracy. Any country that adheres to democracy must ensure the implementation of the State based on the law. This is the state of democratic Law (Democratische Rechtsstaat). Through democracy, every citizen is given the obligation to exercise political rights in order to determine the sustainability of the country. Because through democracy, people can control a legal state.

Countries with a democratic system are required to involve the people in making and making decisions. One of the people's participation forms is the electoral administration. A democracist country involving people in making and making decisions is the participation of citizens in government. The consequence not only of state administratiion that should have the basis and in accordance with the rule of law, but also means the actions of the citizens of the state should not violate the rules of the applicable law. ${ }^{2}$

Democracy is chosen because it is based on human dignity and euality. ${ }^{3}$ This persepective gives justifying that democracy in the Republic is run through the mechanism of general election. General election as a means of creating democracy in a country. ${ }^{4}$

Constitutional foundations of the elections, intended to further provide certainty and legal basis, elections as a form of sovereignty of the people. Article 1 paragraph (2) of 1945 Constitution gives meaning that no other power can exceed the power of the people. However, the values that are based on the people's Power are: The almighty Godhead, the just and the civilized humanity, the Indonesian unity, the people of Indonesia, led by wisdom in the representation of representatives and justice Social. By the foundation of the people's sovereignty by the Pancasila precepts, democracy in Indonesia is called the Democracy of Pancasila.

Pancasila democracy is characterized by three prerequisites, namely: (1) The competition in the fight and defend the power; (2) community participation; (3) The guarantee of civil and political Rights. ${ }^{5}$ These three prerequisites can be realized by the general election because it is considered the epitome and benchmark of democracy itself. ${ }^{6}$ According to Moh Kusnardi and Harmaily Ibrahim, the purpose of the election, is: (1) Enabling safe and orderly transition of government; (2) Implementing the sovereignty of the people; and (3) implementing the human rights of citizens. ${ }^{7}$

B. Arif Sidharta said "Pancasila is a sense of life that is defined by the belief that man was created in association with his neighbor, "men are created intogetherness with each other". Thus, Pancasila democracy is a democracy of the people who are excommunicated and integrated in the rest of the Sila. This means that in the use of democratic rights must always be accompanied by a sense of responsibility to the Almighty God, according to their respective religious beliefs, must uphold the values of humanity according to the dignity and of humanity, must ensure and strengthen the unity of the nation and should be utilized to realize social justice.

Based on various views on democracy, there is a "common element or characteristic" of democracy, which is "people's participation". "People's participation" can be found in the fourth of the Pancasila, namely "The mission of Wisdom in the consultative/representative." Thus, it is necessary to put forward some problems outlined in advance, namely: first, the meaning of the populist led by wisdom; second, discretion or policy; And third, the deliberation/representation.

The term "kerakyatan" has meaning, the sovereign is the people. Another term "Kerakyatan" is also called democracy. Democracy is a government by the people where supreme power is in the hands of the people and executed directly by the people through the its representatives chosen by general elections.

\footnotetext{
${ }^{1}$ Bambang Sunggono, Metodologi Penelitian Hukum, RajaGrafindo Persada, Jakarta, 2010, h.184

2 Tomy Michael, Humanity In The Enforcement Of Anti-Corruption Laws, Jurnal Hukum Bisnis Bonum Commune Volume 2 Nomor 2 Agustus 2019.

${ }^{3}$ Ibid. p. 11

${ }^{4}$ Janedjri M. Gaffar, Politik Hukum Pemilu,Konstitusi Press, Jakarta, 2013. p. 5

${ }^{5}$ Kacung Marijan, Sistem Politik Indonesia: Konsolidasi Demokrasi Pasca Orde Baru, Kencana, Jakarta, 2010. p. 83

${ }^{6}$ Miriam Budiardjo, Dasar-Dasar Ilmu Politik, Gramedia Pustaka Utama, Jakarta, 2009. p. 461

${ }^{7}$ Moh. Kusnardi dan Harmaily Ibrahim, Pengantar Hukum Tata Negara Indonesia, Sinar Bhakti, 1988. p. 330
} 
"Wisdom" means a healthy use or ratio to always consider the nation's unity and unity, the interests of the people and be implemented with a conscious, honest and responsible and encouraged well-suited to the conscience. The phrase comes from a word of wisdom or policy. The Bahasa Indonesia General Dictionary defines "wisdom" as:

1) The wise thing; inteligence uses reason,experience and knowledge;

2) Leadership and action, regarding goverment, society;

3) Acting skills when dealing with others. ${ }^{1}$

Furthermore, the word for's deliberation and representation. The deliberation is a distinctive ordinance of Indonesian personality to formulate and or decide on a matter based on the will of the people, until the decision is reached based on the opinion or consensus. ${ }^{2}$ On the other hand, representation is a system in the sense of the ordinance of working with the people who take part in the life of the state, among others, through institutions or agencies. $^{3}$

Thus, "The circumcision led by wisdom in the deliberation/representation" can be interpreted, the people in the exercise of his power through a representative system. The decisions taken with the deliberation path led by a healthy and full of responsibility, both to God the Almighty and to the people it represents ${ }^{4}$

\section{President and vice president election of the Republic of Indonesia based on Pancasila democratic principles}

In the context of Indonesia, Muhammad Hatta ${ }^{5}$ argues that the nation (democracy) that is embraced by the Indonesian people is not a religion (democracy) that seeks the most votes, but the citizens led by wisdom in the consultative/representative. Indonesian democracy is therefore not a totalitarian democracy, as it relates thoroughly to other precepts. This ethical orientation is turned on through racial power, consensual wisdom, and fairness commitment that can bring a positive synthetic tolerance while preventing power from being controlled by the Majority (mayorocracy) and minority forces of the political elite and the ruler (Minorocracy).

In the deliberative democracy, a political decision is said to be true if it meets at least four of the prasarate. first, it should be based on the principle of rationalism and justice not only based on ideological subjectivity and interests. second, dedicated to the interests of many people is not only the interests of individuals and groups. third, it is far ahead, not the short-term interests of the transactional accommodation being destructive (negative tolerance). fourth, it is impartial by involving and considering the opinions of all parties (even the smallest minority) on an inclusive basis that can resist the dictation of the elite rulers and entrepreneurs as well as claims of majority. ${ }^{6}$

According to Kaelan the democracy is general election, quantitative and directly signifying the pattern of liberal ideology, that democracy is a direct and quantitative election. Such logic has eliminated the philosophy base of the fourth Sila Pancasila which is listed in the opening of the 1945 Constitution. Consequently, various policies in the organizing of the country, the people are only laid as objects, not as subjects, the sovereignty of the people Limited at the time of election."7

The democratic system is directly only implemented to choose representatives who will occupy the position as a representative body to conduct deliberations for consensus in the election of the President and Vice President of the Republic of Indonesian. Therefore, the mandate given by the people to the representative agency is a form of implementation of the concept of sovereignty of the people, while the system of election by the institution representing the people is a manifestation of the principle of Pancasila democracy in the the 4th sila of Pancasila.

The points of the democracy contained in the fourth Sila in the state organizing can be detailed as follows: (1) Indonesian people as citizens and citizens have the same standing and rights; (2) In using their rights always pay attention and consider the interests of people and countries; (3) Having the same position, rights and obligations is essentially not allowed to impose the will on others.(4) In advance of making a decision,the deliberation should be strived and held.(5) Deliberation to reach consensus, overcome by the atmosphere and spirit of togetherness.(6) If it has been seriously strived and maximally unsuccessful, it can be made to make decisions based on the most votes. (7) The poll is not only based on the ratio, but also based on the morality of togetherness.

Basically, democracy of Pancasila recognizes the human nature as individuals and social beings, it is not a liberal democracy that only bases on human nature as individuals only, and not a class democracy that only

\footnotetext{
${ }^{1}$ W.J.S. Poerwadarminta, Kamus Umum Bahasa Indonesia, Balai Pustaka, Jakarta, 1976, p. 138.

2 Dardji Darmodihardjo, Pancasila Suatu Orientasi Singkat, Aries Lima, Jakarta, 1984, p. 59.

3 ibid

${ }^{4}$ Ibid.

${ }^{5}$ Zulkifli Suleman, Demokrasi Untuk Indonesia: Pemikiran Politik Bung Hatta, Penerbit Kompas, Jakarta, 2010. p. 12-13

${ }^{6}$ Materi Sosilalisasi Empat Pilar MPR RI, Sekretariat Jendral MPR RI, Jakarta, 2017 p. 70

${ }^{7}$ Kaelan, Liberalisasi Ideologi Negara Pancasila, Paradigma, Yogyakarta, 2015, p 2.
} 
recognizes mankind as Mere social creatures. Pancasila Democracy has developed a communal democracy, based on a family principle, individual freedoms are placed in the framework of a common welfare.

The principle of democracy based on the values of Pancasila is not only based on the ratio (reason), nor merely laying the principle of democracy in the mathematical perspective, which only through the most voting only, so that the small and the losers Mathematically do not gain space in the context of democracy. Democracy in a unitary state, in addition to mathematical perspectives should lay the foundation of morality in the country's democratic system. Therefore, democracy must be based on the moral of the Godhead, humanity and unity, in order to realize the goal with a prosperous and equitable society. In this sense democracy should base on morality of togetherness with the value of moral wisdom, morality and nobility.

\section{Conclusion}

Philosophically that the nature of the democracy of Pancasila is the government of the people, by the people, and for the people, based on the principle: (a) The deliberation, which is to make the ruling unanimously that carried out jointly through the pathway of wisdom; (b) Execute decisions based on honesty. Unanimous decision to bring the consequences of honesty together. (c) Containing the principle of the people, which is the love of the peoples, fight for the ideals of people, and have a spirit of people. (d) The principle of deliberation for consensus, which is to pay attention and respect the aspirations of all the people through the forum of deliberation, appreciate the difference, prioritize the interests of the people, nations and countries. (e) Led by wisdom is a resourceful, rational, intelligent, skilled, cautious, prudent, thoughtful, honest, and fair leader or whose wisdomwisdom leader leads to a professional leader (wisdomly) through The order and guidance of a consultative/representative.

The system of presidential election and vice President of the Republic of Indonesia in accordance with the principle of the Indonesian-led wisdom in deliberation/representative is the model of representative democracy election with deliberation system for Consensus. While the democratic system is directly only implemented to choose representatives who will occupy the position as a representative body to conduct deliberations for consensus in the general election of the President and Vice President Republic of Indonesia.

\section{Bibliography}

Budiardjo,Miriam, Dasar-Dasar Ilmu Politik, Edisi Revisi, Gramedia Pustaka Utama, Jakarta, 2009.

Darmodihardjo,Dardji, Pancasila Suatu Orientasi Singkat, Aries Lima, Jakarta, 1984.

Gaffar,Janedjri M.,Politik Hukum Pemilu,Konstitusi Press, Jakarta, 2013.

Kaelan, Aktualisasi Pancasila Dalam Kehidupan Berbangsa Dan Bernegara, 5 Juni 2017, Universitas 17 Agustus 1945 Surabaya.

Kaelan, Liberalisasi Ideologi Negara Pancasila, Paradigma, Yogyakarta, 2015.

Kusnardi, Moh. dan Harmaily Ibrahim, Pengantar Hukum Tata Negara Indonesia, Pusat Studi HTN dan CV. Sinar Bakti, Jakarta, 1983.

Marijan,Kacung,Sistem Politik Indonesia: Konsolidasi Demokrasi Pasca Orde Baru, Kencana, Jakarta, 2010.

Materi Sosilalisasi Empat Pilar MPR RI, Sekretariat Jendral MPR RI, Jakarta,2017.

Poerwadarminta,W.J.S., Kamus Umum Bahasa Indonesia, Balai Pustaka, Jakarta, 1976.

Sidharta, B. Arief,Filsafat Hukum Dalam Konteks Ideologi Negara Pencasila, 16-17 Juli 2012.

Suleman,Zulkifli,Demokrasi Untuk Indonesia: Pemikiran Politik Bung Hatta, Penerbit Kompas, Jakarta, 2010.

Sunggono,Bambang, Metodologi Penelitian Hukum, RajaGrafindo Persada, Jakarta, 2010.

Suratman dan Philips Dillah, Metode Penelitian Hukum, Alfabeta, Bandung, 2015.

Tomy Michael, General Election And The Study Of the Future, Jurnal Notariil, Vol. 3, No. 2, November 2018 , 130-136.

Tomy Michael, Humanity In The Enforcement Of Anti-Corruption Laws, Jurnal Hukum Bisnis Bonum Commune Volume 2 Nomor 2 Agustus 2019. 